\title{
Correction to: A triboelectric nanogenerator based on waste plastic bags for flexible vertical interconnection system
}

\author{
Gang $\mathrm{Han}^{1,2} \cdot \operatorname{Bin} \mathrm{Wu}^{1,2} \cdot$ Yilin $\mathrm{Pu}^{1,2}$
}

Published online: 23 October 2020

(C) Springer-Verlag GmbH Germany, part of Springer Nature 2020

\section{Correction to: Microsystem Technologies} https://doi.org/10.1007/s00542-020-04879-6

Unfortunately, the author has missed to update the affiliation in the original article.

The correct affiliations of the authors should be
1. Institute of Microelectronics of Chinese Academy of Sciences, China.

2. University of Chinese Academy of Sciences, China.

Publisher's Note Springer Nature remains neutral with regard to jurisdictional claims in published maps and institutional affiliations.

The original article can be found online at https:// doi.org/10.1007/s00542-020-04879-6.

Gang Han

ganghan2014@163.com

1 Institute of Microelectronics of Chinese Academy of Sciences, 10029 Beijing, China

2 University of Chinese Academy of Sciences, Beijing, China 